DOI 10.14746/ssp.2015.2.12

Maciej MAGIERA

Uniwersytet im. Adama Mickiewicza w Poznaniu

\title{
Postrzeganie bezpieczeństwa a potrzeba mentalnej modernizacji administracji publicznej
}

Streszczenie: W ostatnim ćwierćwieczu oczekiwania społeczne znacznie wzrosły względem administracji publicznej. Już teraz zakres obowiązkowej ochrony narzucanej przez społeczeństwo przybiera rozmiary przerastające możliwości (potencjał) sektora publicznego. W konsekwencji musi dojść do modernizacji administracji publicznej nie tyle w kontekście ograniczonych zasobów i zawężonej organizacji, ale przede wszystkim mentalności. Warto zatem podnieść problem archaicznego sposobu myślenia osób pełniących służbę publiczną, co szczególnie negatywnie oddziałuje na poczucie bezpieczeństwa.

Słowa kluczowe: zarządzanie kryzysowe, poczucie bezpieczeństwa, potrzeba kompleksowego minimalizowania ryzyk, mentalna modernizacja administracji publicznej

$\mathrm{O}$ d przełomu XX i XXI wieku ochrona przed wrogiem zewnętrznym, utrzymanie suwerenności i państwowości czy sama gwarancja przeżycia już nie wystarczają, abyśmy czuli się pewnie. Zaczynamy żądać od państwa stworzenia takich warunków, które ułatwią nam zaspokojenie nie tylko potrzeby fizjologicznej (minimum egzystencji) i potrzeby bezpieczeństwa, ale także potrzeby przynależności, potrzeby uznania i potrzeby samorealizacji. Przecież roszczeniowa postawa obywateli w takich kwestiach jak zapewnienie minimalnego dochodu, bezpłatnej opieki lekarskiej, bezpłatnej nauki na studiach wyższych nie wydaje się czymś nadzwyczajnym. Co więcej, katalog zobowiązań państwa coraz częściej zawiera także gwarancję spełnienia potrzeb mieszkaniowych, zatrudnienia i to zgodnie z kwalifikacjami, a także niejasne pojęcie zapewnienia dobrobytu. Widać wyraźnie, na przykładzie trzech ostatnich potrzeb, że odpowiedzialność indywidualną (obywateli) zastępuje się odpowiedzialnością zbiorową (państwa, samorządu itd.). Tendencja ta, przynajmniej w obszarze zarządzania kryzysowego, wydaje się słuszna, od kiedy zglobalizowana, przez co dynamiczna i wielowątkowa, rzeczywistość stała się niemożliwa do uchwycenia (zrozumienia) przez jednostkę, wykracza to poza jej możliwości. 
Pod wpływem globalizacji doszło do internacjonalizacji (umiędzynarodowienia) problemów wewnętrznych i internacjonalizacji (uwewnętrznienia) problemów międzynarodowych (Kostecki, 2012, s. 64). Jednak nie wolno popadać w skrajności i sprowadzać społeczeństwa do uprzedmiotowionej (bezmyślnej) masy, która ma bezkrytycznie podlegać woli administracji publicznej. Na razie pojawiła się potrzeba kompleksowego minimalizowania ryzyk, czyli żądanie poszukiwania potencjalnych zagrożeń w każdej dziedzinie życia w celu ich identyfikacji i likwidacji. Tego typu zadanie, o tak rozległym zasięgu, należy wręcz zlecić podmiotom o znacznym potencjale, ponieważ w zglobalizowanej rzeczywistości już niewielkim nakładem można wywołać dowolne straty. Należy śmiało stwierdzić, że „w drugiej połowie dwudziestego wieku pojawił się nowy typ sytuacji kryzysowej, która jest wynikiem działalności człowieka. Po raz pierwszy w historii kryzysy tego typu mogą rywalizować z żywiołami zarówno pod względem zakresu, jak i wielkości działania" (Sienkiewicz-Małyjurek, Krynojewski, 2010, s. 121). Warto wspomnieć, że zakres obowiązkowej ochrony narzucanej przez społeczeństwo przybiera rozmiary przerastające instytucje centralne, stąd ich część przenosi się na administrację terenowa, samorządy, a nawet podmioty prywatne.

Przerzucanie odpowiedzialności za bezpieczeństwo na administrację publiczną powoduje, że całokształt jej działalności ocenia się właśnie przez pryzmat zaspokojenia kompleksowej potrzeby minimalizowania ryzyk. W związku z tym narasta tendencja do zabezpieczenia nowych sfer życia poprzez tworzenie kolejnych urzędów, wydziałów, komórek, zwiększa się ich zasoby (siły i środki) lub reorganizuje, co zasadniczo poprawia odbiór społeczny. Pojawia się jednak problem, kiedy powyższe działania przynoszą krótkotrwały efekt lub w konkretnej sytuacji nie sprawdzają $\operatorname{się}^{1}$. Z dużym prawdopodobieństwem można stwierdzić, że oprócz zasobów i organizacji istnieje coś jeszcze co wpływa na efektywność ochrony społeczeństwa. Praktyka podmiotów związanych z zarządzaniem kryzysowym, zainteresowanie wokół ich działalności oraz ocena reagowania w sytuacji kryzysowej prowadzą do pewnego spostrzeżenia: istotne znaczenie odgrywa, jakże subiektywne, poczucie bezpieczeństwa. Cóż z tego, że uda się zneutralizować zagrożenie lub znacznie ograniczyć jego skutki, jeśli nie odbędzie się to w pożądanej przez społeczeństwo formie. Prze-

Należy w tym aspekcie podnieść problem narastającego oporu społecznego wobec przekształceń technologicznych ulepszających system nadzoru, kiedy znacznie limituje to prywatność (Waszkiewicz, Zybertowicz, 2012, s. 248-249). 
cież nadzwyczaj często poszkodowani zwracają uwagę nie na fakt ocalenia od nieszczęścia, ale na sposób dokonania tego, co jakże wyraźnie potwierdzają przekazy medialne, np. z zalanych terenów. Z jednej strony, pomimo utraty dobytku, właściciel pozostaje usatysfakcjonowany, kiedy widział wytężoną i przemyślaną pracę ratowników, np. przy usypywaniu lub wzmacnianiu wałów. Z drugiej, nawet w przypadku udanego ograniczenia skutków powodzi do niewielkiego podtopienia, poszkodowani, kiedy poczuli się lekceważeni, krytycznie odnosili się do działań ratowni$\mathrm{czych}^{2}$. Wydaje się, że potrzeba kompleksowego minimalizowania ryzyk zniekształca sposób odbierania świata i nawet niewielkie, ale dotkliwe doznanie, pogarsza ogólną ocenę. Okazuje się, że w zglobalizowanej rzeczywistości „naturą świata społecznego jest kompleksowość. Kompleksowość oznacza złożoność ładu społecznego, w którym występuje wiele elementów, pomiędzy którymi zachodzą różnorodne interakcje. Systemy społeczne są kompleksowe i działają w kompleksowym otoczeniu, które współtworzą inne [kolejne] systemy społeczne. [Co więcej], kiedy kompleksowość problemów społecznych rośnie geometrycznie, ludzka zdolność do radzenia sobie z tymi problemami rośnie arytmetycznie" (Hausner, 2010, s. 96). W efekcie administracja publiczna stoi przed wielowątkowym i wielopłaszczyznowym problemem zabezpieczenia każdej sfery naszego życia, co utrudnia uchwycenie kwestii bezpieczeństwa w jakiekolwiek niepodważalne ramy. Jednak te komplikacje, rozmycie terminologiczne (ciagle poszerzany obszar ochrony społeczeństwa) czy wieloaspektowe reagowanie (oczekiwanie taktownego zachowania), można ograniczyć, kiedy odwołamy się do kultury bezpieczeństwa ${ }^{3}$ i usystematyzujemy problem badawczy w odniesieniu do jej komponentów. W związku z tym modernizacja administracji publicznej musi przebiegać nie w dwóch, a w trzech aspektach, oprócz zasobów i organizacji pojawiła się mentalność. Łatwo zaobserwować zmiany pierwszego komponentu, kiedy za-

2 Z jednej strony wymaga się od administracji publicznej, szczególnie w sytuacjach kryzysowych, pełnienia służby publicznej. Z drugiej „usłużność jest dziś dobrem rzadkim, m.in. dlatego, że wymaga pewnej koncentracji, uważnego wpatrywania się w potrzeby innych, umiejętności dostrzeżenia czyjegoś drobnego kłopotu" (Dylus, 2007, s. 32).

3 Kultura bezpieczeństwa posiada pojemne znaczenie, ponieważ sprowadza się ją do „sposobu postrzegania wyzwań, szans i zagrożeń, sposobu myślenia o bezpieczeństwie oraz sposobu odczuwania jego braku, a także sposobu zapewnienia bezpieczeństwa" (Cieślarczyk, 2009, s. 44). Składa się ona z trzech komponentów: zasobów (siły i środki), organizacji (prawo) i mentalności. 
chodzi w widoczny sposób wszechobecna modernizacja sił i środków w służbie publicznej, np. unowocześnienie sprzętu ratowniczego, powszechna digitalizacja itp. Dochodzi także do zmian organizacyjnych, kiedy prawo i nie tylko dopasowuje się do dynamicznego i zglobalizowanego otoczenia. Obecnie ożywiona ewolucja aktów prawnych, szczególnie na niższych szczeblach, jak akty prawa miejscowego czy rozporządzenia, potwierdza bieżące dostosowywanie się administracji publicznej do aktualnych żądań społecznych związanych z kompleksową ${ }^{4}$ ochroną. Natomiast $\mathrm{w}$ ramach ostatniego komponentu odbywają się niewielkie ruchy modernizacyjne, choć wydaje się, że proces ten zaczyna nabierać rozmachu. Coraz częściej podnosi się problem archaicznego sposobu myślenia osób pełniących służbę publiczną, który wyróżnia je od pozostałych grup społecznych, szczególnie tych związanych z sektorem prywatnym. Z dużym prawdopodobieństwem graniczącym $\mathrm{z}$ pewnością można powiedzieć, że modernizacja administracji publicznej nie powiedzie się, jeśli główną uwagę skupimy na dwóch pierwszych aspektach - zasobach i organizacji. Cóż z tego, że będziemy zinformatyzowani, zdigitalizowani, dobrze zorganizowani, jeżeli z oporem radykała będziemy odtrącać innowacyjne rozwiązania, ignorować wypracowane zalecenia (obieg informacji) i lekceważyć ryzyka. Często zdarza się, że obojętność przysłania lub dławi (znosi) pozytywne skutki kosztownych modernizacji. Zatem należy pomóc $\mathrm{w}$,przezwyciężeniu psychologicznej bariery «myślenia o rzeczach nie do pomyślenia» przez doskonalenie umiejętności przewidywania i przygotowania na najgorsze. Brak takich umiejętności to jeden z istotnych czynników powodujących powstanie i narastanie sytuacji kryzysowych” (Sienkiewicz-Małyjurek, Krynojewski, 2010, s. 121).

Widać wyraźnie, że społeczna zmiana postrzegania bezpieczeństwa nieodzownie upodobni sektor publiczny, w większości bierny (pasywny), do dynamicznie adaptującego się sektora prywatnego. Doświadczenia państw zachodnich wskazują, że proces ten w polskiej rzeczywistości będzie przyspieszał, szczególnie kiedy pogłębia się współpraca podmiotów publicznych z prywatnymi. Jednak warto przestrzec przed radykalizmem i sprzeciwić się bezrefleksyjnemu kopiowaniu rozwiązań, szczególnie

4 Przymiotnik kompleksowy, w tym przypadku, ,oznacza uwzględnienie wszystkich rodzajów zagrożeń (naturalnych, technologicznych i wojennych), wszystkich poziomów zarządzania, sektorów publicznego i prywatnego oraz ogółu ludności, a także wszystkich czterech faz zarządzania kryzysowego" (Rogozińska-Mitrut, 2010, s. 57). 
tych stosowanych w korporacjach, ponieważ administracja publiczna nie działa dla łatwo mierzalnego zysku, lecz zawsze subiektywnie postrzeganego dobra publicznego. Mimo to pewne ograniczone obszary mogą zostać zaimplementowane bezwarunkowo, choćby w sferze obsługi warto zmodyfikować obecną, choć już nie powszechna, relację urzędnik - petent na urzędnik - klient. Zakres modernizacji musi być określony adekwatnie do wymagań społecznych, w innym przypadku przeprowadzone zmiany mogą w ogóle lub symbolicznie wpłynąć na poczucie bezpieczeństwa. Należy zatem określić społeczną potrzebę kompleksowego minimalizowania ryzyk, a dokładniej rozbić ją na podstawowe elementy charakterystyczne dla określonych grup społecznych. Im bardziej szczegółowo określimy tę potrzebę, tym mniej narazimy się na ewentualne spekulacje, co zwiększy subiektywną ocenę w kwestii jakości wykonywanych usług czy wydajności. Przecież zdecydowana większość z nas opisuje daną rzeczywistość na podstawie własnych doświadczeń i własnych kryteriów, a nawet biernie i bezrefleksyjnie odzwierciedla postawę środowisk opiniotwórczych.

Zatem obecne działanie, ukierunkowane na zwiększanie zasobów czy reorganizację, w ograniczony sposób wpływa na jakość kompleksowej ochrony społeczeństwa. Wydaje się, że sedno tkwi w systemie przekształcania mechanizmów koordynacji działań zbiorowych. Obecnie przeważa imperatywne rządzenie zorientowane na stabilność, a modyfikacje, wdrażane przez kierowniczy ośrodek władzy politycznej, narzucane są z góry. Sukces uda się osiagnąć na drodze rządzenia interaktywnego, a ściślej społecznego dyskursu, kiedy wyzwoli się „zdolność uczestników systemu społecznego do aktywnego przystosowania się i tworzenia nowych rozwiązań poprzez proces społecznego komunikowania, negocjowania i porozumiewania się" (Hausner, 2010, s. 98). Wtedy to, modernizacja administracji publicznej będzie na tyle elastycznym procesem, że umożliwi wprowadzanie oddolnych korekt, co sprzyja efektywności i szybkości dostosowywania się do jakże zmiennych warunków sytuacji kryzysowej.

W ten sposób wyłania się problem, a raczej potrzeba, zmiany naszej mentalności właśnie z tej biernej, ukierunkowanej na realizację narzuconych z góry zadań, na aktywną, sprzyjającą oddolnemu procesowi dostosowawczemu. Inaczej nie uniknie się rozbieżności między oczekiwaną przez społeczeństwo a rzeczywistą służbą administracji publicznej. Przecież „działanie systemu ochrony ludności na każdym szczeblu zarządzania w państwie warunkowane jest zbiorem oczekiwań społecznych" (Grocki, 2012, s. 87). Co ważne, realizacja zadań na pożądanym obecnie poziomie 
nie może obyć się bez mentalnej modyfikacji całego społeczeństwa. Przecież „kultura organów władzy i administracji publicznej oraz kultura społeczeństwa są gwarantem sukcesu w działalności bieżącej na rzecz bezpieczeństwa" (Wiśniewski, 2013, s. 327). Niewiele zyskamy, kiedy ulepszymy zasoby, organizację i mentalność służb, inspekcji i straży oraz innych podmiotów zainteresowanych naszym bezpieczeństwem, a poszczególne jednostki (poszkodowani) nadal będą zachowywać się nieroztropnie, a nawet dziecinnie. Przecież zdarzają się przykłady zaniedbań lub celowych działań, które z oczywistych względów doprowadzą do kryzysu, co często wynika z przesadnej chciwości. Czyż nie jesteśmy świadkami systematycznych powodzi na byłych terenach zalewowych bezrefleksyjnie zabudowywanych, ze względu na niską cenę ziemi, domami jednorodzinnymi?

Warto z początku zainteresować się mentalną modernizacją administracji publicznej, ze względu na jej zasadniczą rolę w systemie bezpieczeństwa publicznego. Dotąd udało się dowieść, że społeczna potrzeba kompleksowania minimalizowania ryzyk narzuciła w zarządzaniu kryzysowym obowiązek zmiany mentalności biernej na aktywną, a zatem docelowo osoby zajmujące decyzyjne stanowiska publiczne powinny charakteryzować się mentalnością menedżera, co prowadzi do pożądanych przez społeczeństwo następstw. Po pierwsze, pojawia się poczucie odpowiedzialności, strategiczne myślenie, przewidywanie czy zdolność do kalkulacji. Po drugie, ułatwia się poszkodowanej lokalnej społeczności zdobycie wsparcia z programów pomocowych na wyższych szczeblach. Po trzecie, zacieśnia się współpraca z prywatnym sektorem, np. z ubezpieczycielami przy wycenie strat czy z instytucjami finansowymi przy kredycie lub pożyczkach. Po czwarte, pojawia się oddolna potrzeba samokształcenia, ponieważ ,aby menedżer mógł skutecznie i efektywnie realizować swoje zadania, musi mieć doświadczenie i rzetelną wiedzę. Niestety, samo doświadczenie albo tylko sama wiedza, w przypadku zarządzania kryzysowego, nie są wystarczające" (Grocki, 2012, s. 49). Po piąte, nie dochodzi do ignorowania pożądanej jakościowo informacji (aktualnej, zrozumiałej i wiarygodnej), co wpływa na efektywność zarządzania kryzysowego. Przecież ośrodek kierujący akcją ratowniczą „,bez znajomości charakteru zagrożenia, jego analizy i wyciągnięcia wniosków z otrzymanych materiałów, nie będzie miał możliwości przeprowadzenia efektywnych i skutecznych działań w zakresie ochrony ludności, dóbr itp." (Rogozińska-Mitrut, 2010, s. 55). Po szóste, dochodzi do maksymalizacji korzyści, kiedy wnikliwie obserwuje się rozwój społeczności, aby w porę rozpoznać potencjal- 
ne lub już istniejące, choć ukryte, zagrożenia. Określenie wrażliwości lokalnej społeczności prowadzi także do poznania oczekiwań tej grupy, co nie pozostaje obojętne na późniejszą ocenę działalności antykryzysowej.

Gruntowna zmiana trzeciego komponentu, zawsze silnie zakorzenionego w społeczeństwie, wymaga czasu, zdecydowanych działań i przede wszystkim permanentnych szkoleń. Zasoby czy organizację można modyfikować przy pomocy prawa, ale przecież przekształcenie mentalności nie da się narzucić odgórnie na drodze ustaw, rozporządzeń czy bardziej szczegółowych wewnętrznych zarządzeń. Sukces nastąpi tylko wtedy, kiedy wypracuje się określone pożądane nawyki, a dokładniej, kiedy administracja publiczna zacznie charakteryzować się samouczącym i samoregulującym się mechanizmem ${ }^{5}$. Najważniejsza kwestia sprowadza się do wywołania pozytywnego wrażenia u poszkodowanego, który odczuje zainteresowanie i opiekę w czasie nieszczęścia.

Z bezpośredniej obserwacji działalności administracji publicznej, szczególnie w okresie trwania Euro 2012 w Poznaniu, można wyłonić dwa priorytetowe, choć ogólne, spostrzeżenia. Po pierwsze, należy bezwzględnie propagować i uświadamiać jakie znaczenie odgrywa obieg informacji w każdej fazie zarządzania kryzysowego, a szczególnie w fazie reagowania. Po drugie, trzeba przemóc, wydaje się błędne, choć powszechne, przekonanie o destrukcyjnym i paraliżującym działalność antykryzysową niedofinansowaniu.

Pierwsze spostrzeżenie wymaga sporządzania pewnej, sprawdzonej i poprawnie przetworzonej informacji ${ }^{6}$. Jej jakość będzie zależeć od umiejętności stworzenia wartościowego, przydatnego komunikatu, to znaczy

${ }^{5}$ Według Jerzego Hausnera, kiedy dojdzie do wytworzenia się takiego mechanizmu, administracja publiczna z modelu idealnej biurokracji dążyć będzie do klasycznego modelu zarządzania publicznego, tzn. biurokratyczny styl kierowania będzie menedżerskim zarząadzaniem, hierarchiczne i sztywne struktury organizacyjne staną się zdywersyfikowane i elastyczne, ukierunkowanie działań do wewnątrz i na procedury zastąpi się działaniami na zewnątrz i na potrzeby, krótkookresowy horyzont podejmowanych działań stanie się długookresowym i przede wszystkim pojawi się tendencja do zmiany organizacji państwa z dominacji układów monocentrycznych i resortowych na dominację układów samorządowych i autonomicznych (Hausner, 2010, s. 95).

${ }^{6}$ Informacja powinna być dokładna (wedle potrzeb odbiorcy), elastyczna (wykorzystywana przez różnych użytkowników), jednoznaczna (niebudząca wątpliwości), rzetelna (pozbawiona spekulacji), wartościowa (usuwająca niepewność) i wystarczalna (na jej podstawie można podjąc decyzję) (Korzeniowski, 2012, s. 159). 
niezbędnego do podjęcia optymalnej w określonych warunkach decyzji oraz spersonalizowanego dla wybranej instytucji i dopasowanego do określonego szczebla. „W erze informacyjnej można mówić o nadmiarze informacji, czy wręcz chaosie informacyjnym. Dlatego też tak istotną rolę stanowi pozyskanie umiejętności zbierania, gromadzenia, interpretacji, przetwarzania i dystrybucji informacji adekwatnie do zakładanych potrzeb" (Stępień, 2011, s. 442). Chodzi o to, aby na podstawie tak dobranych danych móc dokonać słusznego (racjonalnego) wyboru, np. o ewakuacji czy o określeniu kierunku i zakresu udzielanej pomocy. Należy zatem szkolić w zakresie zdolności zdobywania informacji, umiejętności ich przetwarzania oraz bezzwłocznego przekazywania do wszystkich zainteresowanych podmiotów. W ostatnim przypadku nie chodzi o masowe rozsyłanie każdej treści, ale przede wszystkim o umiejętne jej skompilowanie do istotnych danych, które zainteresują konkretnego odbiorcę. Informacja o przyjeżdżającym pociągu pełnym kibiców powinna zostać przekazana Policji, korporacji taksówkowej, wolontariuszom, przedsiębiorstwu komunikacji miejskiej, ale przesadą wydaje się przesłanie jej przedstawicielowi portu lotniczego czy inspekcji sanitarno-epidemiologicznej. W konsekwencji pierwszy cel szkolenia powinien ograniczać się do wdrukowania określonych nawyków (bliskich menedżerom) oraz wyuczenia przytoczonych wyżej umiejętności, aby ograniczyć jakże często spotykaną przypadkowość w działaniach antykryzysowych ${ }^{7}$. Efekt szkoleń sprowadza się więc do ukazania słuchaczom w jaki sposób obieg informacji oddziałuje na macierzystą instytucję czy współpracujące z nią podmioty i jak mocno pozostaje on uzależniony od naszej mentalności. Zatem słuszność decyzji wynika $\mathrm{z}$,pewnego podzbioru skomplikowanych procesów myślowych leżących na przecięciu dwóch głównych, sprzężonych ze sobą zbiorów: informacji i socjopsychicznych cech ludzi (wiedzy, emocji, motywacji)" (Flakiewicz, 1990, s. 39).

Odnosząc się do drugiego spostrzeżenia, argumentacja o niedofinansowaniu regularnie zdaje się być nadinterpretowana i w efekcie często używa się jej do usprawiedliwienia niepowodzeń. Jednak nad wyraz często potrzebę kompleksowego minimalizowania ryzyk udaje się zaspokoić mimo ewidentnych niedoborów. W przypadku katastrofy kolejowej pod

7 Znaczne ograniczenie tej przypadkowości możliwe będzie także, kiedy decydenci wyrobią w sobie odporność osobowościową, czyli będą posiadać poczucie zrozumiałości, poczucie zaradności i poczucie sensowności (Niewiadomska, 2009, s. 134). 
Szczekocinami, będącej jednoznacznie masowym zdarzeniem, pozytywny odbiór społeczny akcji ratowniczej wynikał z szybkości jej rozpoczęcia. Pierwsi ratownicy, były to osoby z ochotniczej straży pożarnej, dotarli na miejsce już po kilku minutach od zderzenia pociagów. Zatem nie chodzi o to, aby zdarzenie, nawet to masowe, natychmiast zabezpieczyć pod każdym względem (kompleksowo), ale aby w jak najkrótszym czasie poszkodowani otrzymali (odczuli) pierwszą pomoc. W tej kwestii zasadniczą rolę odgrywa nie zasób finansowy czy organizacja, ale właśnie mentalność, a dokładniej racjonalność decyzji podejmowanej dzięki umiejętności przetworzenia ograniczonych danych i dopasowania reagowania do określonych warunków kryzysu. Następnie, na podstawie doświadczeń nabytych w czasie szkoleń, wraz z rozwojem sytuacji należy odpowiednio ukierunkować (rozszerzać) akcję ratowniczą.

Na zakończenie warto dodać, że obowiązek mentalnej modernizacji administracji publicznej, w wyniku pojawienia się potrzeby kompleksowego minimalizowania ryzyk, napotyka dwa zasadnicze problemy. Po pierwsze, ustawodawca nie wprowadził obligatoryjnych szkoleń, co przy tworzeniu ustawy o zarządzaniu kryzysowym uzasadniano brakiem możliwości przewidzenia skutków finansowych. W efekcie teoretycznie administracja publiczna spełnia warunki narzucone przez ustawodawcę w dwóch pierwszych komponentach (zasobach i organizacji), ale trudno orzec przydatność mentalną urzędników ${ }^{8}$. W praktyce ewentualna archaiczność mentalności uwidacznia się, nie w toku szkoleń, ale bezlitośnie ujawnia się właśnie w czasie rzeczywistej sytuacji kryzysowej. Po drugie, warto dodać, że mentalna modernizacja administracji publicznej nie może obejść się bez zwiększania autonomii na każdym szczeblu9. Proces ten pociaga jednak za sobą powinność, aby zwierzchnicy brali pod uwagę ryzyko niepowodzenia u podwładnych, inaczej taka autonomia, ze względu na oczekiwaną przez przełożonych nieomylność, staje się pozorna. Z drugiej strony należy zachować rozsądek, żeby nie doszło do masowych

8 Obecne, jakże często w administracji publicznej, takie ,,poleganie jedynie na planach reagowania kryzysowego jest niczym innym, jak czekaniem na możliwie najlepszy i szczęśliwy dla zarządzających rozwój sytuacji kryzysowej” (Pepłoński, 2013, s. 181).

9 Ważne, aby proces ten przeprowadzano indywidualnie dla danego organu czy instytucji, ponieważ do automatycznej (masowej) autonomizacji ,przechodzi się dopiero po osiagnięciu wysokiego poziomu wyćwiczenia, wprawy i manipulacyjnej sprawności w podejmowaniu decyzji” (Habuda, Habuda, 2000, s. 14). 
błędnych działań. W efekcie nie tylko wiedza (ogół wiarygodnych informacji wraz z umiejętnością ich wykorzystywania), ale i doświadczenie odgrywa zasadniczą rolę, a to, ze względu na dynamiczne otoczenie wywołane postępem technicznym i technologicznym, prowadzi do obowiązku systematycznego dokształcania się i podnoszenia kwalifikacji. Inaczej administracja publiczna, głównie za sprawą archaicznej mentalności i mimo modernizacji zasobów czy reorganizacji, będzie nieskuteczna dla społeczności, będzie rozmijać się ze społecznymi oczekiwaniami.

\section{Bibliografia}

Cieślarczyk M. (2009), Tożsamość stużb reagowania kryzysowego w świetle socjologicznego modelu kultury bezpieczeństwa, w: Tożsamość społeczna grup dyspozycyjnych, red. J. Maciejewski, W. Nowosielski, Wydawnictwo Uniwersytetu Wrocławskiego, Wrocław.

Dylus A. (2007), Stużba (publiczna): cnota zapomniana, w: Etos urzędnika, red. D. Bąk, Wydawnictwa Akademickie i Profesjonalne, Warszawa.

Flakiewicz W. (1990), Informacyjne systemy zarzqdzania, Państwowe Wydawnictwo Ekonomiczne, Warszawa.

Grocki R. (2012), Zarzqdzanie kryzysowe, Difin, Warszawa.

Habuda A., Habuda L. (2000), Teorie decyzji w odniesieniu do administracji publicznej, w: Administracja i polityka. Proces decyzyjny w administracji publicznej, red. L. Habuda, Wydawnictwo Uniwersytetu Wrocławskiego, Wrocław.

Hausner J. (2010), W kierunku rzqdzenia interaktywnego, w: Nowe zarzqdzanie publiczne i public governance $w$ Polsce i $w$ Europie, red. A. Bosiacki, H. Izdebski, A. Nelicki, I. Zachariasz, Liber, Warszawa.

Korzeniowski L. (2012), Podstawy nauk o bezpieczeństwie, Difin, Warszawa.

Kostecki W. (2012), Strach i potęa. Bezpieczeństwo międzynarodowe w XXI wieku, Wydawnictwo Poltext, Warszawa.

Niewiadomska I. (2009), Osobowościowa odporność na sytuacje trudne jako czynnik konstytuujacy bezpieczeństwo publiczne, w: Psychologia na rzecz bezpieczeństwa publicznego, red. E. Szafrańskiej, A. Szołtek, Wydział Wydawnictw i Poligrafii Wyższej Szkoły Policji, Szczytno.

Pepłoński A. (2013), Dylematy zarzq̨dzania kryzysowego na szczeblu lokalnym, w: Zarzqdzanie kryzysowe. Wybrane problemy, red. A. Pepłoński, G. Kędzierska, Z. Siemak, Niepaństwowa Wyższa Szkoła Pedagogiczna, Białystok.

Rogozińska-Mitrut J. (2010), Podstawy zarzqdzania kryzysowego, Oficyna Wydawnicza ASPRA-JR, Warszawa.

Sienkiewicz-Małyjurek K., Krynojewski F. (2010), Zarzqdzanie kryzysowe w administracji publicznej, Difin, Warszawa. 
Stępień J. (2011), Zastosowanie symulacji konstruktywnej w procesie szkolenia podmiotów zarzqdzania kryzysowego, w: Zarzadzanie kryzysowe w systemie bezpieczeństwa narodowego, red. G. Sobolewski, D. Majchrzak, Akademia Obrony Narodowej, Warszawa.

Waszkiewicz J., Zybertowicz A. (2012), Mobilność w społeczeństwie postindustrialnym a zmiany w mechanizmach kontroli spotecznej-perspektywa socjologiczno-historyczna, w: Za kulisami. Szkice o władzy, interesach i bezpieczeństwie, red. K. Pietrowicz, P. Stankiewicz, Zysk i Spółka, Białystok.

Wiśniewski B. (2013), System bezpieczeństwa państwa, Wydział Wydawnictw i Poligrafii Wyższej Szkoły Policji, Szczytno.

\title{
Perception of security and the need for the mental modernisation of public administration
}

\begin{abstract}
Summary
In the last years the social expectations have increased significantly relative to public administration. Already, the scope of compulsory protection imposed by the society exceeds the capability of the public sector. As a result we need to modernize of public administration, not so much in the context of limited resources and narrow organization, but primarily mentality. It is worth raise the issue of the archaic way of thinking, which particularly negatively impacts on the sense of security.
\end{abstract}

Key words: crisis management, sense of security, demand to comprehensive minimize risk, mentality modernisation of public administration 
